\title{
ABSTRAK \\ BAHAYA ZAT ADITIF RHODAMIN B PADA MAKANAN
}

\author{
Surati, Dosen Prodi Pendidikan Biologi IAIN, Ambon, \\ 081231226671, E-mail: qmia7068@ gmail.com
}

\begin{abstract}
Penggunaan zat aditif menjadikan makanan bebas dari kehidupan mikroba baik yang bersifat patogen maupun non pathogen yang dapat menyebabkan kerusakan bahan makanan seperti pembusukan. Dalam makanan yang kita konsumsi, kita tidak mengetahui apakah di dalam makanan tersebut terdapat zat pewarna sintetis yang dilarang atau tidak, khususnya Rhodamin B merupakan zat aditif yang sangat berbahaya bila dikonsumsi dalam jangka waktu yang panjang. Makanan yang mengandung zat pewarna Rhodamin B memiliki warna makanan yang terang mencolok. Selain itu, memiliki rasa agak pahit. Apabila kita ingin melakukan pewarnaan makanan yang murah namun dengan tidak melibatkan zat-zat kimia yang dapat merusak kesehatan, kita dapat menggunakan daun jambu atau daun jati (warna merah). Analisis untuk zat aditif Rhodamin B yaitu menggunakan reaksi warna metode gravimetri (kualitatif) dan metode spektrofotometri (kuantitatif).
\end{abstract}

\section{Kata kunci; zat aditif, rhodamin B}

\begin{abstract}
ANALYSIS SUBSTANCE ADDITIVES RHODAMIN B ON FOOD

Use a food additive substance-free good life of a microbial pathogens and non-pathogens that can cause damage such as decaying food. In the food we consume, we do not know whether there is food in the synthetic dye substances which are prohibited or not, especially Rhodamin B is a substance that is very dangerous additives when consumed in long time. Foods containing coloring Rhodamin B has a striking bright color food. In addition, a slightly bitter taste. When we want to eat cheap food coloring but with not involve chemical substances that can damage health, we can use guava leaves or teak leaves (red). Analysis for nutrient additives Rhodamin B that is using the color reaction gravimetric method (qualitative) and spectrophotometric methods (quantitative)
\end{abstract}

Keywords: nutrient additives, rhodamin B 
Makanan merupakan elemen penting bagi tubuh manusia. Hal ini disebabkan karena makanan memberikan energi dan tenaga bagi tubuh untuk melakukan bekerja. Mengkonsumsi makanan yang sehat menjadi harapan setiap manusia karena asupan gizi yang cukup, memberikan energi yang maksimal bagi tubuh. Jadi, jika kita harus mendisiplinkan diri untuk hidup sehat dan mangatur pola makan yang baik untuk kesehatan tubuh kita. Dewasa ini, banyak sekali kasus keracunan makanan mewarnai media cetak maupun televisi. Ada juga kasus kematian yang merupakan akibat dari keracunan makanan. Kasus keracunan makanan yang dilaporkan tidak hanya bersumber pada ketidak higienisan makanan. Namun, adanya fenomena penggunaan bahan-bahan kimia yang dilarang dalam makanan juga turut mendominasi.

Penggunaan bahan tambahan atau zat aditif pada makanan semakin meningkat, terutama setelah adanya penemuan termasuk keberhasilan dalam mensintesis bahan kimia baru yang lebih praktis, lebih murah, dan lebih mudah diperoleh. Penambahan bahan zat aditif ke dalam makanan merupakan hal yang dipandang perlu untuk meningkatkan mutu suatu produk sehingga mampu bersaing di pasaran. Bahan tambahan tersebut diantaranya: pewarna, penyedap rasa dan aroma, antioksidan, pengawet, pemanis, dan pengental

Secara umum bahan aditif ini dapat dibedakan menjadi dua yaitu: (1) aditif sengaja yaitu aditif yang secara sengaja ditambahkan untuk meningkatkan konsistensi, citarasa, mengendalikan keasaman/kebasaan, dan memantapkan bentuk dan rupa; (2) aditif tidak sengaja yaitu aditif yang memang telah ada dalam makanan (walaupun sedikit) sebagai akibat dari proses pengolahan. Begitu juga halnya, bahan pengawet yang ada dalam makanan adalah untuk membuat makanan tampak lebih berkualitas, tahan lama, menarik, serta rasa dan teksturnya lebih sempurna.

Penggunaan bahan pengawet dapat menjadikan bahan makanan bebas dari kehidupan mikroba baik yang bersifat patogen maupun non pathogen yang dapat menyebabkan kerusakan bahan makanan seperti pembusukan. Apabila pemakaian bahan pengawet tidak diatur dan diawasi, kemungkinan besar akan menimbulkan suatu permasalahan terutama bagi 
konsumen. Bahan pengawet yang lapangan untuk makanan, rhodamin B diijinkan hanya bahan yang bersifat (warna merah) dan Metanil Yellow menghambat, bukan mematikan (kuning) sering dipakai mewarnai organisme-organisme pencemar. Oleh kerupuk, makanan ringan, terasi, kembang karena itu, sangat penting diperhatikan gula, sirup, biskuit, sosis, makaroni bahwa penanganan dan pengolahan bahan pangan dilakukan secara higinies.

goreng, minuman ringan, cendol, manisan, gipang, dan ikan asap.

Salah satu contoh bahan kimia berbahaya yang digunakan produsen makanan yang perlu diwaspadai konsumen adalah zat pewarna merah Rhodamin B. Beberapa hasil penelitian banyak ditemukan zat pewarna Rhodamin B pada produk industri rumah tangga. Rhodamin $B$ adalah bahan kimia yang digunakan untuk pewarna merah pada industri tekstil plastik dan kain. Kelebihan dosis Rhodamin B bisa menyebabkan kanker, keracunan, iritasi paru-paru, mata, tenggorokan, hidung, dan usus. Masih adanya penggunaan zat berbahaya pada makanan karena efek yang ditimbulkan dari mengkonsumsi makanan tercemar tersebut tidak langsung seketika terasa. Penyakit akan timbul setelah beberapa tahun kemudian akibat residu yang mengendap dalam tubuh. Berbeda saat keracunan makanan karena kurang higienitas bisa terasa setelah mengkonsumsi suatu makanan. Di

\section{PEMBAHASAN}

\section{Preparasi Sampel}

Preparasi sampel adalah proses yang dilakukan untuk menyiapkan sampel sehingga siap untuk dianalisis menggunakan instrumentasi yang sesuai. Alat: Spektrofotometer yang mampu mengukur secara akurat terhadap larutan pada daerah 400-750 nm dengan simpangan $\leq 10 \mathrm{~nm}$. Reagen: Reagen adalah bahan yang digunakan dalam reaksi kimia. Penentuan sampel standar murni yaitu sampel standar harus dipreparasi secara hati-hati agar kemurnian yang tinggi dapat dicapai. Pelarut: Pelarut yang digunakan bebas dari bahan tersuspensi (campuran heterogen dari zat cair dan zat padat yang dilarutkan dalam zat cair tersebut)

\section{Uji Kualitatif}

Prosedur kerja yang dilakukan uji kualitatif adalah: Jika sampel tak larut dalam air gunakan air panas, aseton, 
alkohol, xilena, atau larutan alkali. Berikut prosedur kerja analisa sampel dalam air panas :

1. Larutkan 2 gram sampel dalam 200 $\mathrm{mL}$ air panas dan dinginkan pada suhu ruang.

2. Selanjutnya saring endapan yang terbentuk dengan corong gelas. Kemudian, panaskan pada suhu 135 ${ }^{0} \mathrm{C}$ dan timbang.

3. Setelah itu, cuci dengan air dingin hingga tak terbentuk warna.

4. Keringkan pada suhu $135{ }^{\circ} \mathrm{C}$ selama 3 jam, dinginkan dalam desikator, dan timbang.

5. Laporkan peningkatan berat sebagai bahan tak larut dalam air.

Sedangkan untuk pelarut aseton, alkohol, xilena, atau larutan alkali, prosedur kerja yang dilakukan sebagai berikut :

1. Campurkan 0,2-0,5 gram sampel dengan $100 \mathrm{~mL}$ masing-masing pelarut dalam gelas beker $250 \mathrm{~mL}$, stirer, dan panaskan pada titik didih pelarut.

2. Saring larutan panas dan pindahkan residu ke dalam gelas beker untuk menyaring. Cuci dengan $10 \mathrm{~mL}$ pelarut hingga tak berwarna.

3. Keringkan selama 3 jam pada suhu 100-105 ${ }^{0} \mathrm{C}$ dan timbang. Laporkan peningkatan berat sebagai bahan tak larut dalam pelarut yang disebutkan.

4. Bila tidak larut dalam semua pelarut di atas, gunakan larutan karbon tetraklorida, toluena, atau benzena. Dengan prosedur kerja yang sama dengan pelarut aseton.

\section{Uji Kuantitatif}

1. Standarisasi

Prosedur kerja yang dilakukan sebagai berikut :

a. Siapkan beberapa larutan yang sudah diketahui konsentrasi sampel standarnya dan tentukan absorbansi larutan.

b. Koreksi absorbansi pelarut dan sel pada panjang gelombang yang sesuai (panjang gelombang pada saat absorbansi maksimum).

c. Atur konsentrasi larutan untuk memberikan nilai absorbansi dari 0,41,0 dengan instrumen dan sel yang digunakan. Kemudian, plotkan data yang diperoleh.

2. Penentuan

Prosedur kerja yang dilakukan

sebagai berikut : 
a. Siapkan larutan sampel dalam pelarut yang sama (pada saat standarisasi). Kemudian, tentukan absorbansi larutan pada kondisi yang sama pada saat standarisasi.

b. Selanjutnya, hitung kandungan zat aditif (Rhodamin B) sampel dari absorbansi larutan sampel dan absorbansi larutan standar.

Bahan Tambahan Pangan adalan bahan atau campuran bahan yang secara alami bukan merupakan bagian dari bahan baku pangan, tetapi diambahkan kedalam pangan untuk mempengaruhi sifat atau bentuk pangan, salah satunya adalah zat pewarna Rhodamin B. Rhodamin B adalah pewarna sintetis yang berasal dari metanlinilat dan difenilalanin yang berbentuk serbuk kristal berwarna kehijauan, berwarna merah keunguan dalam bentuk terlarut pada konsentrasi tinggi dan berwarna merah terang pada konsentrasi rendah.

$$
\text { Zat pewarna Rhodamin B }
$$
merupakan zat warna sintetis, berwarna merah keunguan, yang digunakan sebagai zat warna untuk kertas dan tekstil. Sering disalah gunakan untuk pewarna pangan dan kosmetik. Misalnya: sirup, terasi, kerupuk, lipstik, dll. Ciri-ciri makanan yang diberi Rhodamin B adalah warna makanan yang terang mencolok. Biasanya makanan yang diberi pewarna untuk makanan warnanya tidak begitu merah terang mencolok.

Bahaya utama terhadap kesehatan yaitu pemakaian dalam waktu lama (kronis) dapat menyebabkan radang kulit alergi, dan gangguan fungsi hati/kanker hati. Tanda-tanda dan gejala akut bila terpapar Rhodamin B:

1. Jika terhirup dapat menimbulkan iritasi pada saluran pernafasan.

2. Jika terkena kulit dapat menimbulkan iritasi pada kulit.

3. Jika terkena mata dapat menimbulkan iritasi pada mata, mata kemerahan, dan udem pada kelopak mata.

4. Jika tertelan dapat menimbulkan gejala keracunan dan air seni berwarna merah atau merah muda.

Kita dapat mengenali ciri makanan yang menggunakan Rhodamin B, yaitu biasanya makanan yang diberi zat pewarna ini lebih terang atau mencolok warnanya dan memiliki rasa agak pahit. Disamping itu, apabila kita ingin melakukan pewarnaan makanan yang murah namun dengan tidak melibatkan zat-zat kimia yang dapat merusak 
kesehatan, kita dapat menggunakan daun jambu atau daun jati (warna merah).

Analisis zat aditif Rhodamin B dapat diidentifikasi bahan volatilnya pada suhu $135{ }^{0} \mathrm{C}$ dan bahan tak larut di dalamnya dengan metode gravimetri, serta warna total dalam pelarut air dengan metode spektrofotometri. Uji kualitatif dilakukan dengan cara sampel yang tak larut dalam air, digunakan pelarut air panas, aseton, alkohol, xilena, atau larutan alkali. Prosedur kerja yang dilakukan sebenarnya adalah metode gravimetri (uji kuantitatif) tetapi metode ini merupakan metode awal (uji pendahuluan) terhadap sampel yang mengandung Rhodamin B. Selebihnya bisa dilakukan uji kuantitatif, yaitu penimbangan. Selain uji kuantitatif dengan metode gravimetri, dapat juga digunakan metode spektrofotometri. Dalam metode ini dilakukan penbuatan standarisasi sampel sebagai koreksi atau kalibrator. Selanjutnya, dapat ditentukan kandungan zat aditif (Rhodamin B) dalam sampel menggunakan rumus.

\section{KESIMPULAN}

Dalam makanan yang kita konsumsi, kita tidak mengetahui apakah di dalam makanan tersebut terdapat zat pewarna sintetis yang dilarang atau tidak, khususnya Rhodamin B merupakan zat aditif yang sangat berbahaya bila dikonsumsi dalam jangka waktu yang panjang. Berdasarkan pembahasan, dapat disimpulkan bahwa makanan yang mengandung zat pewarna Rhodamin B memiliki warna makanan yang terang mencolok. Selain itu, memiliki rasa agak pahit. Apabila kita ingin melakukan pewarnaan makanan yang murah namun dengan tidak melibatkan zat-zat kimia yang dapat merusak kesehatan, kita dapat menggunakan daun jambu atau daun jati (warna merah). Analisis untuk zat aditif Rhodamin B yaitu menggunakan reaksi warna metode gravimetri (kualitatif) dan metode spektrofotometri (kuantitatif).

\section{SARAN}

Bagi masyarakat, perlu adanya pengetahuan dan informasi yang cukup tentang zat-zat kimia yang terkandung dalam makanan (Rhodamin B) pada masyarakat serta pengawasan keluarmasuknya (perdagangan) zat kimia sangat penting untuk meminimalkan penyalahgunaan zat-zat kimia tersebut. Oleh sebab itu, respon dan tindakan dari pemerintah sangatlah diharapkan. 
DAFTAR PUSTAKA

AOAC. 1970. Analysis Method Second Edition. Association of Official Agriculture Chemists. United State of America.

Anonim. 2013. Penjelasan Zat Aditif Pada Makanan. http://diam2belajar.blogspot.com

Bellardo Kenny. 2009. Bahan Tambahan Pangan. Program Studi Teknologi Industri Pangan D4 Jurusan Teknik Kimia Politeknik Negeri Ujung Pandang

Buckle, K. A., Edward R. A., Fleet G. H.,Souness R., and Wotton M., 1985, Ilmu Pangan, a.b. Hari Purnomo dan Adiono, UI-Press, Jakarta

Departemen Kesehatan RI, 2003. Keputusan menteri kesehatan RI Tentang Persyaratan Hygiene Sanitasi Jasa Boga. Depkes RI. Jakarta

Ervina. 2011. Bahaya Makanan yang Menggunakan Zat. http://ervinanana.blogspot.com/, diakses pada 30September 2014

Hamdani, S. 2012. Rhodamin B. http://catatankimia.com/, diakses pada 30 September 2014

Pedoman Pertolongan Keracunan untuk Puskesmas, Buku IV Bahan Tambahan Pangan Sentra Informasi Keracunan, Pusat Informasi Obat dan Makanan. Badan POM RI. 2005.

Tranggono, Z.N., Wibowo D., Murdjiati G., dan Mary A. 1990. Kimia Nutrisi Pangan. PAU Pangan dan Gizi. UGM. Jogjakarta.

Undang-undang RI tahun 1996 nomor 7 Tentang Pangan.
Winarno, F.G. 1992. Kimia Pangan dan Gizi. Gramedia. Jakarta 